\title{
Filipino Physical Education Teachers' Technological Pedagogical Content Knowledge on Remote Digital Teaching
}

\author{
Jem Cloyd M. Tanucan, Ma. Rosita A. Hernani, and Felix Diano Jr.
}

\begin{abstract}
This study examined the Filipino physical education (PE) teachers' technological pedagogical content knowledge (TPACK) on remote digital teaching approach. More specifically, it looked into their preparedness on remote digital teaching using the TPACK model, the relationship between their demographics, and the seven dimensions of knowledge of TPACK model and its interrelationship using a descriptive correlational research design. The sample was composed of 1,402 PE teachers across the three major islands of the Philippines who, using online survey, answered a 19-item questionnaire with a five-point Likert scale about their TPACK on remote digital teaching. Using the Pearson Product Moment Correlation and Chi-Square test of Independence, the study yielded four major results: 1) PE teachers have an average level of preparedness to conduct remote digital teaching in all domains of knowledge of TPACK; 2) The preparedness level of the $P E$ teachers to conduct remote digital teaching in all domains of knowledge of TPACK is dependent to their age, sex and teaching experience, except technological knowledge, as it is independent to their highest educational attainment; and 3). There is a significant interrelationship on the PE teachers' preparedness to conduct remote digital teaching among all domains of knowledge of TPACK. Hence, in order to successfully navigate a paradigm in education that accentuates the utilization of technology and other digital platforms, teachers have to be equipped with the tri-relationship of knowledge - content, pedagogy, and technology - through capability-building activities that consider their demographics and background.
\end{abstract}

Index Terms-Physical education, remote digital teaching, teachers, technological pedagogical content knowledge.

\section{INTRODUCTION}

The COVID-19 pandemic has left no aspect of life unscathed and education, on this matter, is no exception. Due to the nature of the virus particularly its transmission, it has altered human behaviors, relations, and lifestyles that impacted the ways on how education should be done in concordance with the health and safety protocols set by each nation's government. This consequently has caused most educational institutions worldwide, including in the Philippines to temporarily close which affected more than 1.2

Manuscript received January 9, 2021; revised May 29, 2021

Jem Cloyd M. Tanucan and Ma. Rosita A. Hernani are with the Cebu Normal University, Philippines (e-mail: tanucanj@cnu.edu.ph, hernanim@cnu.edu.ph).

Felix Diano Jr. is with the University of the Visayas - Main Campus, Philippines (e-mail: diano@uv.edu.ph). billion learners globally with more than 28 million learners in the Philippines [1]. Cognizant of the adverse impact of prolonged school closure, education officials have rolled out remote digital teaching - a feasible alternative to continue education that accentuates synchronous and asynchronous teaching, distance education, and module-based learning using technology and other digital platforms [2]-[5]. In the Philippines, although not explicitly stated as such, remote digital teaching is being encouraged to be used for both basic and tertiary education level through the Department of Education's Learning Continuity Plan (LCP) [6] and Commission on Higher Education's advisory [5]. However, its implementation posed a great challenge to the teachers as re-engineering of different learning activities and tasks can be taxing with the limited time, material and technical resources, and training.

While it may be argued that remote digital teaching is feasible, given that Filipinos are among the top users of Internet and social media worldwide [7], the lack of preparation of teachers to conduct this type of approach along with the country's perennial problem like poor internet connection and digital infrastructure and technologies [8] are strong threats. Although online seminars and trainings were done to enhance the teachers capabilities and competencies on e-learning, online education or remote digital teaching in general [4], [9], this would not be enough to respond their copious needs. Thus, examining the knowledge of teachers toward remote digital teaching is a vital step to properly address their concerns while responding at the same time to the existing problem on the slow integration of technology in education.

Many studies revealed that teachers find the integration of technology in educational practice as a complex innovation [10], [11]. The primary reason is that they lack the competency, knowledge, and self-confidence with technology [12]-[14]. Furthermore, it is pointed out that the effective integration of technology in education requires from the teachers the prowess that can embroil the nexus of curriculum requirements [15], learning needs of the students, technologies' affordances and constraints, and the realities and contexts of school environment, which can be fundamentally achieved by possessing the Technological Pedagogical Content Knowledge (TPACK).

Extended from the model of Shulman [16], [17] pedagogical content knowledge (PCK) -TPACK is a theoretical construct of teacher knowledge which comprises seven domains. This includes the three main domains or primary knowledge - Technological Knowledge (TK), Pedagogical Knowledge (PK) and Content Knowledge (CK) 
[16] and the four integrated domains - Pedagogical Content Knowledge (PCK), Technological Content Knowledge (TCK), Technological Pedagogical Knowledge (TPK), and Technological Pedagogical Content Knowledge (TPACK) [18]. Ref. [19] and Ref. [20] explained that teachers have to develop the said seven domains of knowledge to ensure quality integration of technology in their classes. These domains are explained in Table I.

TABLE I: THE SEVEN DOMAINS OF TPACK AND THEIR RESPECTIVE DEFINITIONS

\begin{tabular}{cl}
\hline $\begin{array}{c}\text { Seven Domains of } \\
\text { TPACK }\end{array}$ & \multicolumn{1}{c}{ Definition } \\
\hline CK & The knowledge of subject matter. \\
\hline PK & $\begin{array}{l}\text { The knowledge of instructional methods } \\
\text { and strategies. }\end{array}$ \\
\hline TK & The knowledge of technological tools. \\
\hline PCK & $\begin{array}{l}\text { The knowledge of applying appropriate } \\
\text { instructional strategies to teach subject } \\
\text { content. }\end{array}$ \\
\hline TCK & $\begin{array}{l}\text { The knowledge of applying technology that } \\
\text { fits to the subject content. }\end{array}$ \\
\hline TPK & $\begin{array}{l}\text { The knowledge of applying technology to } \\
\text { employ instructional strategies. }\end{array}$ \\
\hline TPACK & $\begin{array}{l}\text { The knowledge of facilitating students' } \\
\text { learning of a specific content through the } \\
\text { consideration of the most fitting pedagogy } \\
\text { and technology }\end{array}$ \\
\hline \hline
\end{tabular}

Utilizing the TPACK model has been seen to contribute to teacher's professional development [21] as it engages a broad spectrum of teacher's knowledge that caters not only the three important aspects - content, pedagogy, and technology, but the amalgamation of the three. Since its formal inception and establishment as a theoretical concept, TPACK has been used to assess teachers' technology-related professional development efforts [22], [23]. It has also been successfully used as a framework to analyze and improve curricular subjects such as Science, Mathematics, [24], [25] and English [26]. Little is known, however, about the integration of TPACK as a framework for understanding the successful implementation of technology in physical education (PE) subjects.

Technology is becoming an inseparable part of PE curriculum. In the recent years, due to the rapid advancement of technology worldwide, new interests and technological tools are integrated in PE to ensure effective and efficient implementation of the subject and produce desirable health and learning outcomes to the students. Researchers and practitioners have identified different instructional, sport, and PE related technologies that can potentially enhance the effectiveness of teaching the subject, such as wireless technology, computer projection systems, digital monitoring systems for physical activity or exercise, and active gaming devices, and sports or exercise software [27]. With this, PE teachers' technological know-how has become crucial for the successful integration of technology in the classroom. Additionally, today's education is highly integrating technology and other digital platforms through the context of remote digital teaching, which made it more necessary to normalized technology-embedded instruction. Further, as PE has been traditionally considered as a practical and hands-on subject in schools that centers on physical activity, PE teachers are one of the most vulnerable groups to be impacted in this paradigm shift [28]. Thus, PE teachers in this time of pandemic and in the age of remote digital teaching need as much support as they can to keep pace.

Prior studies on the efficiency and potentiality of PE implemented digitally or online are scarce [29]-[31]. The common scenario is that $\mathrm{PE}$ teachers are resorting to trial-and-error approach in implementing PE in this time of pandemic [32] which can possibly compromise the value of the subject and the learning outcomes of the students. This shows that despite the increased access to technology [33], educators are not integrating technology as effective or efficient as expected or needed [34], [35]. Technology integration per se is a complex task that requires teachers to consider several factors that influence implementation, including their personal demographics.

Studies revealed that there is a difference on how men and women learn and engage on the tasks that involve online transactions, technology, and other digital platforms [36], [37]. This establishes a notion that the TPACK varies in both men and women, which the study of [38] can support, citing: the difference of TPACK sub-dimensions - the PK and TPK - according to gender in favor to female.

Other studies also pointed out that knowledge dimensions of TPACK, including technology, are dependent to age and teaching experience. More specifically, Hofer and Harris [39] highlighted the need of differentiating pre-service TPACK-based training module for more experienced teachers which implies the association of age and teaching experience in the adeptness of technology training or use and TPACK. This is in agreement with the studies of [40] and [41] which revealed that the higher the teachers' experience, the lower their confidence with their TPACK.

Meanwhile, one of the factors that affects a teacher's attitude in the integration of technology in class is the professional development activities they received or pursued, such as trainings [12], [42] or further studies [43]. The studies of [44] and [43] also found out that teachers prowess on technology can vary in terms of educational attainment as it is hypothesized that access to technology or learning the use of technology can be high if they are to venture on further studies. In other words, educational attainment can be a potential factor when studying the TPACK of professionals like the teachers.

It is seen that numerous literatures and studies have been conducted with regard to TPACK model; however, most of them were directed in the context of technology integration in face-to-face education and not in remote digital teaching. More so, majority of the information about TPACK are saturated to foreign countries and studies regarding the Filipino teachers' TPACK are in wanting. Lastly, the common investigation were saturated in subject areas like Science, Math, and English, but rarely focused on PE subjects. Hence, more research is needed to be conducted within the specified gaps.

\section{Statement of the Problem:}

This study examined the PE teachers' preparedness on remote digital teaching using the TPACK model, the link between their demographics, and the seven domains of knowledge of TPACK and its interrelationship. Doing this will unearth many aspects of the teacher's knowledge on 
remote digital teaching which can help guide school administrators and human resource development officers in their quest to mitigate the impact of the pandemic through providing quality human resource development in education. More specifically, this study sought to answer the following research questions:

(1) What is the demographic profile of the respondents in terms of:
(a) Age
(b) Sex
(c) Year of Teaching
(d) Highest Education Attainment

(2) How prepared are the PE teachers to conduct remote digital teaching in terms of the seven domains of TPACK.

(3) Is there a significant relationship between the demographic profile of teachers and their preparedness to conduct remote digital teaching?

(4) Is there a significant interrelationship among the seven domains of knowledge?

\section{MATERIAL AND METHODS}

Using descriptive correlational approach, this study sought to statistically quantify the Filipino PE teachers' TPACK on remote digital teaching. Respondents of the study were the 1,402 PE teachers across the three major islands of the Philippines who were recruited using online recruitment methods. Details of their demographics were presented in Table II.

A 19-item questionnaire being subdivided into two parts was used in this study and respondents answered it online. Part 1 is about the respondent's demographics and Part 2 is a 5-point Likert-scale adapted and modified from the survey questionnaire developed by [45] which originally consist of a 5-point Likert-scale and 47-item measuring the seven domains of TPACK. One modified concept is the use of Statements of Quality for the Likert-scale (Poor, Below Average, Average, Above Average, and Excellent) instead of using the original Statement of Agreement (Strongly Disagree, Disagree, Neither Agree/Disagree, Agree, Strongly Agree) in measuring teachers' preparedness on remote digital teaching. Additionally, some statements in the questionnaire were retained (e.g., TK question: I have the technical skills to play around technology/gadgets) as they are universally applicable for all teachers. Some statements were likewise omitted specially on the items that involve non-PE subjects like math, literacy, science, and social studies and were replaced with PE to cohere with the objective of the study. Thereafter, content validation was made by two experts in the field of education technology and two experts in PE. Then, when tested for reliability particularly the items of knowledge dimensions of TPACK, the instrument showed a high Cronbach Alpha coefficient of .98 .

Statistical analysis of the data was performed through the Statistical Package for Social Sciences (SPSS) version 16.0. The Pearson Product Moment Correlation and Chi-Square test of Independence were respectively used to examine the correlation among the variables of the study. The alpha value for both statistics was set to 0.05 .

\section{RESUlTS}

As shown in Table II below, there were 1,402 PE teachers in all levels of education who answered the online survey and many of them belong to the millennial generation. More than half of the respondents were females which indicated that most of the PE teachers who are into participating in various online surveys and/or internet users are female. Respondents have comparable teaching experience for the three groups (1-3 years; 4-9 years and 10-24 years) except for the 25+ year's group which is understandable given that the data collection was done through online survey. More than half of them did not proceed to further graduate studies.

TABLE II: DEMOGRAPHIC PROFILE OF THE RESPONDENTS

\begin{tabular}{|c|c|c|}
\hline Profile & $\mathbf{F}$ & $\%$ \\
\hline \multicolumn{3}{|l|}{ Age } \\
\hline $18-24$ years old & 221 & 15.76 \\
\hline 25 - 35 years old & 555 & 39.59 \\
\hline $36-44$ years old & 380 & 27.10 \\
\hline 45 - 54 years old & 193 & 13.77 \\
\hline 55- 64 years old & 52 & 3.71 \\
\hline $65-74$ years old & 1 & 0.07 \\
\hline \multicolumn{3}{|l|}{ Sex } \\
\hline Male & 521 & 37.16 \\
\hline Female & 881 & 62.84 \\
\hline \multicolumn{3}{|l|}{ Years Teaching } \\
\hline $1-3$ years & 427 & 30.46 \\
\hline $4-9$ years & 463 & 33.02 \\
\hline $10-24$ years & 413 & 29.46 \\
\hline $25+$ years & 99 & 7.06 \\
\hline \multicolumn{3}{|l|}{$\begin{array}{c}\text { Highest Educational } \\
\text { Attainment }\end{array}$} \\
\hline Bachelor's Degree & 893 & 63.69 \\
\hline Master's Degree & 454 & 32.38 \\
\hline Doctorate Degree & 55 & 3.92 \\
\hline
\end{tabular}

Note. $n=1402$.

After the demographics of the respondents were analyzed, the researchers proceeded to the analysis of their level of preparedness on remote digital teaching. As revealed in Table III, PE teachers have an average level of preparedness to conduct remote digital teaching in accordance with the seven domains of knowledge (CK, PK, TK, PCK, TCK, TPK, and TPACK). This means that PE teachers in general have the basic theoretical and practical knowledge in the conduct of remote digital teaching.

The data collection of this study happened in the month of August, the common opening month of the school year 2020 in almost all schools in the Philippines, in order to ensure that teachers who will answer the questionnaire have the theoretical and practical knowledge on the conduct of remote digital teaching as they have received several capacity-building trainings in the past few months. As per the data collected, all the participants were able to participate in trainings related to PE content (100\%), teaching strategy for remote digital learning (100\%), and different technology applications and software that they can use for remote digital learning $(100 \%)$. Their average participation in trainings 
within the month of April 2020 to August 2020 is 5 trainings. Cognizant of the data related to their training engagements on remote digital teaching, the result of this study - average level of preparedness to conduct remote digital teaching can be a reflection of learning that PE teachers gained after the different capacity-building trainings they received before the school year started.

TABLE III: PREPAREDNESS OF PE TEACHERS TO CONDUCT REMOTE DiGITAL TEACHING

\begin{tabular}{cccc}
\hline \hline Domains of Knowledge & Mean & SD & Interpretation \\
\hline Content Knowledge (CK) & 3.21 & 0.75 & Average \\
\hline $\begin{array}{c}\text { Pedagogical Knowledge } \\
\text { (PK) }\end{array}$ & 3.17 & 0.74 & Average \\
\hline $\begin{array}{c}\text { Technological Knowledge } \\
\text { (TK) }\end{array}$ & 3.26 & 0.76 & Average \\
\hline $\begin{array}{c}\text { Pedagogical Content } \\
\text { Knowledge (PCK) }\end{array}$ & 3.18 & 0.74 & Average \\
\hline $\begin{array}{c}\text { Technological Content } \\
\text { Knowledge (TCK) }\end{array}$ & 3.10 & 0.84 & Average \\
\hline $\begin{array}{c}\text { Technological Pedagogical } \\
\text { Knowledge (TPK) }\end{array}$ & 3.20 & 0.83 & Average \\
\hline $\begin{array}{c}\text { Technological Pedagogical } \\
\text { Content Knowledge } \\
\text { (TPACK) }\end{array}$ & 3.19 & 0.78 & Average
\end{tabular}

Note. $n=1402$. 1.00-1.80 - Poor; 1.81-2.60 - Below Average; 2.61-3.40 - Average; 3.41-4.20 - Above Average; 4.21-5.00 - Excellent.

Thereafter, the researchers examined the relationship between the demographic profile of the teachers and their preparedness to conduct remote digital teaching. As presented in Table IV below, the preparedness level of the PE teachers to conduct remote digital teaching in all the domains of knowledge is dependent to their age, sex, and number of years in the teaching profession, except technological knowledge, as it is independent to their highest educational attainment.

TABLE IV: RELATIONSHIP BETWEEN THE DEMOGRAPHIC PROFILE OF RESPONDENTS AND THEIR PREPAREDNESS TO CONDUCT REMOTE DIGITAL

\begin{tabular}{llllllll}
\multicolumn{7}{c}{ PROFILE } & \multicolumn{7}{c}{ Demains of Knowledge } \\
\cline { 2 - 8 } & CK & PK & TK & PCK & TCK & TPK & TPACK \\
\hline \hline Age & 44. & 77.9 & 1.64 & 48.59 & 83.92 & 1.488 & 93.680 \\
& 030 & $93 * *$ & $7 E 2$ & $5 * *$ & $8 * *$ & E2** & $* *$ \\
& $* *$ & & $* *$ & & & & \\
\hline Sex & 25. & 46.0 & 57.2 & 13.99 & 29.17 & 32.14 & 25.327 \\
& 373 & $55 * *$ & 41 & $2 * *$ & $8 * *$ & $5 * *$ & $* *$ \\
& $* *$ & & $* *$ & & & & \\
\hline Years & 47. & 23.3 & 85.0 & 42.84 & 53.09 & 75.05 & 58.610 \\
Teaching & 753 & $60 *$ & 74 & $7 * *$ & $7 * *$ & $3 * *$ & $* *$ \\
& $* *$ & & $* *$ & & & & \\
\hline Highest & 22. & 25.5 & 11.9 & 31.38 & 20.74 & 19.98 & 31.341 \\
Educational & 140 & $14 * *$ & 35 & $2 * *$ & $3 * *$ & $4 *$ & $* *$ \\
Attainment & $* *$ & & & & & \\
\hline \hline
\end{tabular}

Note. Chi-square test of independence. ${ }^{*}{ }^{*} p<0.01 .{ }^{*} p<0.05$.

Finally, the researchers analyzed the interrelationship of PE teachers' preparedness to conduct remote digital teaching among the seven domains of knowledge of TPACK as shown in Table V. Using the Pearson Product Moment Correlation, a significant interrelationship on the PE teachers' preparedness to conduct remote digital teaching among the seven domains of knowledge was found $(p<0.01)$. The highlight is that the $\mathrm{CK}$ of the teachers are strongly correlated to their PCK, TPK, and TPACK which suggests that having an understanding on the basic configurations of subject matter is advantageous, especially when implementing remote digital teaching approach, where the utilization of technology or digital platforms is being accentuated during the teaching and learning process. In addition, the PK of the teachers are strongly correlated to their PCK, TPK, and TPACK, which connotes that understanding the different approaches of teaching-learning process can assist in rolling out remote digital teaching approach as a mode for teaching and learning process. Furthermore, the TK of the teachers are moderately correlated to their TCK, TPK, and TPACK, which means that developing the TK of the teachers is essential to be emphasized when implementing remote digital teaching approach as it is linked to their knowledge to conduct classes in terms of content, pedagogy, technology and their combination.

TABLE V: INTERRELATIONSHIP ON THE PE TEACHERS' PREPAREDNESS TO Conduct REMote Digital TEACHING AMONG THE SEVEn (7) DOMAINS OF KNOWLEDGE OF TPACK

\begin{tabular}{|c|c|c|c|c|c|c|}
\hline DOMAINS & $\mathrm{CK}$ & PK & TK & PCK & TCK & TPK \\
\hline PK & $0.771 * *$ & & & & & \\
\hline TK & $0.500 * *$ & $0.617 * *$ & & & & \\
\hline PCK & $0.810^{* *}$ & $0.758 * *$ & $0.528 * *$ & & & \\
\hline TCK & $0.674 * *$ & $0.671 * *$ & $0.583 * *$ & $0.708 * *$ & & \\
\hline TPK & $0.704 * *$ & $0.713^{* *}$ & $0.642 * *$ & $0.666^{* *}$ & $0.806^{* * *}$ & \\
\hline TPACK & $0.768 * *$ & $0.731 * *$ & $0.550 * *$ & $0.741 * *$ & $0.774 * *$ & $0.797 * *$ \\
\hline
\end{tabular}

\section{DISCUSSION}

Due to the COVID-19 pandemic, most institutions of learning, if not all, have taken a back seat with the face-to-face teaching including laboratories and other practical learning experiences to mitigate the widespread of the virus. Accordingly, governments of many countries implemented social isolation strategies, limited mobility, and stringent surveillance that wedged schools to abruptly adapt remote digital teaching where technology and other digital learning platforms are accentuated [46]-[48]. However, due to the lack of resources, insufficient mind-setting, and time constraint, curriculum implementers, at the onset, were seen to be ill-prepared for this situation. This is evident in the hasty preparation of teachers in terms of learning materials and necessary knowledge for remote digital teaching. In the Philippine setting, no studies examining teachers' preparedness to conduct remote digital teaching using the seven domains of knowledge of TPACK model has been conducted yet. Hence, this study is engendered.

As the results of the study suggested, PE teachers in general have an average preparedness to conduct their classes using remote digital teaching approach. This can be attributed to the diverse web-based capability building activities given to them in order to ensure that they are provided with the necessary understanding and skills in rolling out remote digital teaching amidst the pandemic [49], [50]. This also shows that despite the Philippines being one of the countries with slow internet connectivity and poor digital infrastructure and technologies [8], [51], its teachers are responsive to the call of duty to educate [52]. The digitization project of the Department of Education and the enhancement of technology in the Philippines [53]-[55] might also have played a role in the teachers' acquisition of 
technical skills. However, as technology is getting more complex and diversified in the contemporary age, having an average-level of knowledge on technology may not be sufficient for teachers to keep pace. Educational leaders and administrators have to explore options and select innovative and technology-based methods that will help teachers to best complement the contents they are teaching in line with digitization and industrialization [56], [18]. Relevant trainings on that regard should also be expanded in order to reach every teacher who needs them and to scale-up the current level of teachers' technological knowledge.

It has been noted in many studies that the teachers' use of technology in their classroom instructions, such as those that involve the hardware, software, and internet [57], is generally insufficient to enhance student learning experiences [57], [58], [18]. Ref. [57] also pointed out that the common technology utilization in the classroom is the performance of low-level tasks such as drill practice and reward activities. In the Philippines where science and technology is still insufficient and lagging behind other developing nations, this problem is its current reality or worse. Promotion and trainings for teachers about technology in education should not only create awareness and knowledge in the nitty-gritty of existing low-tech interventions and gadgets (e.g. paper-based activities and radio programs) but also develop confidence and opportunities for them to apply and use varied and more up-to-date digital platforms so that the implementation of education in times of pandemic becomes more equitable, accessible, and meaningful to the learners [59]-[61].

On the other hand, although the results of the study have shown that PE teachers can still roll out their classes using remote digital teaching, it cannot be denied that there are those teachers who are left behind in this paradigm shift. The older teachers who are commonly referred to as "technology migrants" may have felt the brunt of technological divide, which can be impacting in terms of their lesson designs and activities as well as the overall learning of their students. As shown in Table IV, the preparedness of the teachers to conduct remote digital teaching in all the domains of knowledge is dependent to age. While the shift to remote digital teaching is great for upskilling teachers, it can pose great challenges to older generation who are into traditional face-to-face teaching. Having to unlearn and relearn new skills and complicated things for teaching are herculean tasks to anybody and much worse to older teachers or by default those with higher teaching experience. This also explains why in the study's findings, teaching experience is a dependent factor of the successful conduct of remote digital teaching. Age and teaching experience are two strongly related factors which are often in tandem as it usually follows that teachers who have the most experience are at the same time the oldest. It is for this reason that the study of [39] highlighted the need of differentiating pre-service TPACK-based training module for more experienced teachers as it has been known in the previous studies that teachers with high experience tends to have a lower confidence with their TPACK [40], [41]. Hence, teachers who have higher teaching experience or by default those who are in the older age group should be given prominence during training on remote digital teaching approach. Schools, being the key promoter of remote digital teaching approach - like distance learning education - should be able to provide a more conscious and considerate training and workshops for the teachers in order to successfully equip them with the necessary skills and knowledge [62].

On the other hand, the results in Table IV also showed that PE teachers' preparedness in the implementation of remote digital teaching approach in terms of all the domains of knowledge is dependent to their sex. This supports previous studies which capitalized that sex or gender can be an important factor to determine the adeptness in the implementation or orchestration of a learning environment that involves technology [36]-[38]. For instance, the study of [63], asserted that women learned differently from men and that they are inherently successful in the online learning environment as they learn in a more relational methods where drawing on connections are their key forte - a skill necessary for online learning environment. The study of [64] also found out that women were more receptive to online learning than male students. Further, Ref. [65] expounded that females have a stronger intrinsic motivation to take online courses than males. Thus, together with the literatures indicated, this study affirms that there is a dissimilarity on how men and women learn and engage remote digital teaching, especially on the tasks that involve online transactions, technology and other digital platforms, with women tending to be more receptive and well- adept to this kind of approach than men.

Moreover, the results in Table IV also showed that PE teachers' technological knowledge is independent to their highest educational attainment. In other words, the content of the theories and knowledge about the technologies necessary for the conduct of remote digital teaching - be it in the form of modular and online - is the same for all PE teachers regardless of their level of education. With the advent technological revolution and internet connectivity, the traditional model of unidirectional instruction has been increasingly set aside in preference to the utilization of multimedia and technology integration [66], [67]. It has been well studied that technology in the classroom presents new possibilities for living, effective teaching, and quality learning [67]-[69]; Hence, technology usage and integration have been apparent in most classrooms. With this, having a knowledge on technology is not a matter of who has the highest level of education, but on other attributes such as teacher's exposure to trainings in the use and implementation of technology in the classroom [70]-[73] or teachers' belief about technology [74]. More so, educational attainment should not be the basis as to who will receive trainings on technology, citing the common perception that technological training is only for those who are smart. Technology trainings are for everyone and they are to be delivered in a manner that caters individual needs, situations or preference.

Alternatively, understanding that there is a significant interrelationship on the PE teachers' preparedness to conduct remote digital teaching among the seven domains of knowledge (Table V) is an important basis for a number of studies specifically in understanding as to how PE teachers can implement remote digital teaching approach in their classes. More specifically, based on the findings, PE 
teachers' primary knowledge level (TK, PK, and CK) were significantly correlated to the rest of knowledge domains. This means that it is important for teachers to have a good grasp of understanding on the basic primary knowledge of their subject matter $(\mathrm{CK})$, teaching and learning approaches (PK) and different technological or digital platforms (TK) in order to successfully implement their lessons using remote digital teaching approach. This conforms to the findings of the study of [75] which expounded that teachers' primary knowledge level such as the TK, PK, and CK are significant predictors of their respective second level knowledge bases TPK, TCK, PCK, and the overall TPACK. In other words, when implementing a new teaching approach, especially when the integration of technology is involved, one has to consider the curricular, pedagogical, and technological knowledge of the teachers. To ensure that remote digital teaching is successfully implemented, PE teachers have to strengthen their primary knowledge as they ultimately shape their technological, pedagogical and content knowledge (TPACK) - an important aspect of knowledge to be examined when implementing a kind of teaching approach that accentuates the utilization of technology and other digital platforms.

\section{CONCLUSION AND RECOMMENDATION}

With the advent of remote digital teaching prompted by the pandemic, teachers are required to possess knowledge that connects the affordances of various technological and digital platforms to the transformation of content and pedagogy. PE teachers who are accustomed to implement their classes in a face-to-face, personalized manner can be more adaptive to this kind of innovation in education by having a basket of knowledge founded by the tri-relationship of content, pedagogy, and technology. Additionally, to make this possible, it should involve an understanding and consideration of their demographics as adapting a teaching modality that embraces the complexities of technology is not a "one-size-fits-all" approach. Hence, learning and development programs for teachers must be tailored-fit according to their context and situations in order for them to easily and effectively navigate the intricacies of remote digital teaching.

\section{CONFLICT OF INTEREST}

The authors declare no conflict of interest.

\section{AUTHOR CONTRIBUTIONS}

J.C.M.T. was responsible for the overall design and conduct of the study. M.R.A.H. was responsible for the data collection process of the study. F.D.Jr. was responsible for the data analysis process of the study.

\section{ACKNOWLEDGMENT}

The researchers would like to thank the respondents of this study for despite their hectic schedule, they made time to answer the online questionnaire given to them.

\section{REFERENCES}

[1] UNESCO. COVID-19 educational disruption and response. [Online] Available: https://en.unesco.org/covid19/educationresponse

[2] S. J. Daniel, "Education and the COVID-19 pandemic," Prospects, vol. 49, pp. 91-96, 2020.

[3] D. C. Barton, "Impacts of the COVID-19 pandemic of field of instruction and remote teaching alternatives: Results from a survey of instructors," Academic Practice in Ecology and Evolution, vol. 10, pp. 12499-12507, 2020.

[4] A. Bozkurt and R. C. Sharma, "Emergency remote teaching in a time of global crisis due to CoronaVirus pandemic," Asian Journal of Distance Education, vol. 15, no. 1, pp. i-vi, 2020.

[5] CHED. (2020). CHED COVID-19 ADVISORY NO. 3. [Online] Available:

https://ched.gov.ph/wp-content/uploads/CHED-COVID-2019-Adviso ry-No.-3.pdf

[6] Dep.Ed. (2020). Official Statement Department of Education. [Online] Available: https://www.deped.gov.ph/2020/05/06/official-statement-2

[7] C. E. Baclig, "Filipinos remain most active internet, social media users globally - Study," Inquirer.Net., Feb. 2020.

[8] World Bank. "Building a better normal under COVID-19: Harnessing digital technologies in the Philippines," Jan. 2021

[9] G. Basilaia and D. Kvavadze, "Transition to online education in schools during a SARS-CoV-2 coronavirus (COVID-19) pandemic in Georgia," Pedagogical Research, vol. 5, no. 4, 2020.

[10] M. Webb and M. Cox, "A review of pedagogy related to information and communication technology," Technology, Pedagogy and Education, vol. 13, pp. 235-286, 2004.

[11] J. Voogt, F. Tilya, and J. Akker, "Science teacher learning for MBL-supported student-centered science education in the context of secondary education in Tanzania," Journal of Science Education and Technology, vol. 18, pp. 429-428, 2009.

[12] R. Aldunate, and M. Nussbaum, "Teacher adoption of technology," Computers in Human Behavior, vol. 29, no. 3, pp. 519-524, 2013.

[13] T. J. Kopcha, "Teachers' perceptions of the barriers to technology integration and practices with technology under situated professional development," Computers \& Education, vol. 59, no. 4, pp. 1109-1121, 2012.

[14] O. Uslu and N. T. Bümen, "Effects of the professional development program on 178 Turkish teachers: Technology integration along with attitude towards ICT in education," Turkish Online Journal of Educational Technology, vol. 11, no. 3, 115-127, 2012.

[15] J. B. Harris and M. J. Hofer, "Technological pedagogical content knowledge (TPACK) in action," Journal of Research on Technology in Education, vol. 43, no. 3, pp. 211-229, 2011.

[16] L. S. Shulman, "Those who understand: Knowledge growth in teaching," Educational Researcher, vol. 15, no. 2, pp. 4-14, 1986.

[17] L. S. Shulman, "Knowledge and teaching: Foundation of the new reform," Harvard Educational Review, vol. 57, no. 1, pp. 1-22, 1987.

[18] J. H. L. Koh, C. S. Chai, and M. H. Lee, "Technological pedagogical content knowledge (TPACK) for pedagogical improvement: Editorial for special issue on TPACK," The Asia-Pacific Education Researcher, vol. 24, no. 3, pp. 459-462, 2015.

[19] M. J. Koehler, P. Mishra, M. Akcaoglu, and J. M. Rosenberg, "The technological pedagogical content knowledge framework for teachers and teacher educators," ICT Integrated Teacher Education: A Resource Book, Vancouver, BC:CEMCA, 2013.

[20] P. Mishra and M. Koehler, "Technological pedagogical content knowledge: A framework for teacher knowledge," Teachers College Record, vol. 108, no. 6, pp. 1017-1054, 2006.

[21] S. Malik, D. Rohendi, and I. Widiaty, "Technological pedagogical content knowledge (TPACK) with information and communication technology (ICT) integration: A literature review," presented at 5th UPI International Conference on Technical and Vocational Education and Training. Indonesia (ICTVET 2018), Atlantis Press, 2019.

[22] T. Altun and S. Akyildiz, "Investigating student teachers' technological pedagogical content knowledge (TPACK) levels based on some variables," European Journal of Education Studies, vol. 3, no. 5, pp. 467-485, 2017.

[23] S. Liu, H. Tsai, and Y. Huang, "Collaborative professional development of mentor teachers and pre-service teachers in relation to technology integration," Educational Technology and Society, vol. 18, no. 3, pp. 161-172, 2015. 
[24] R. A. Salas-Rueda, "TPACK: Technological, pedagogical and content model necessary to improve the educational process on mathematics through a web application?" International Electronic Journal of Mathematics Education, vol. 1, 2019.

[25] B. Rienties, N. Brouwer, K. B. Carbonell, D. Townsend, A.-P. Rozendal, J. Loo, P. Dekker, and S. Lygo-Baker, "Online training of TPACK skills of higher education scholars: A cross-institutional impact study," European Journal of Teacher Education, vol. 36, pp 480-495, 2013.

[26] M. Debbagh, and W. M. Jones, "Examining English language teachers' TPACK in oral communication skills teaching," Journal of Educational Multimedia and Hypermedia, vol. 27, no. 1, pp. 43-62, 2018.

[27] NASPE, Appropriate Use of Instructional Technology in Physical Education, Position Statement, Reston, VA: NASPE, 2009.

[28] V. Varea, G. González-Calvo, and A. García-Monge, "Exploring the changes of physical education in the age of Covid-19," Physical Education and Sport Pedagogy, pp. 1-11, 2020.

[29] H. J. Lm and S. J. Kim, "Development and application of e-learning contents to pre-service physical education teacher education," Korean Association of Sport Pedagogy, vol. 14, pp. 21-40, 2007.

[30] M. J. Lyu, "A case study on structure and possibility of online courses in physical education," Journal of Research in Curriculum Instruction. vol. 15, pp. 353-370, 2011.

[31] S. H. Hong, "A study on teaching and learning plan of physical education in middle school using blended learning strategy linked," Korean J. Phys. Educ. vol. 45, pp. 387-402, 2006.

[32] H. Jeong and W. So, "Difficulties of online physical education classes in middle and high school and an efficient operation plan to address them," International Journal of Environmental Research and Public Health, vol. 17, no. 19, p. 7279, 2020.

[33] C. Kim, M. K. Kim, C. Lee, J. M. Spector, and K. DeMeester, "Teacher beliefs and technology integration," Teaching \& Teacher Education, vol. 29, pp. 76-85, 2013.

[34] M. Gumbo, M. Makgato, and H. Müller, "The impact of in-service technology training programs on technology teachers," Journal of Technology Studies, vol. 38, no. 1, pp. 23-33. 2012.

[35] A. D. Ritzhaupt, K. Dawson, and C. Cavanaugh, "An investigation of factors influencing student use of technology in K-12 classrooms using path analysis," Journal of Educational Computing Research, vol. 46 , no. 3, pp. 229-254, 2012.

[36] T.-C. Lin, C.-C. Tsai, C. S. Chai, and M.-H. Lee, "Identifying science teachers' perceptions of technological pedagogical and content knowledge (TPACK)," Journal of Science Education and Technology, vol. 22, no. 3, pp. 325-336, 2013.

[37] R. Scherer, J. Tondeur, and F. Siddiq, "On the quest for validity: Testing the factor structure and measurement invariance of the technology-dimensions in the technological, pedagogical, and content knowledge (TPACK) model," Computers \& Education, vol. 112, pp. $1-17,2017$

[38] I. Y. Kazu and P. Erten, "Teachers' technological pedagogical content knowledge self efficacies," Journal of Education and Training Studies, vol. 2, no. 2, pp. 126-144, 2014.

[39] M. Hofer and J. Harris, "Differentiating TPACK-based learning Materials for preservice and inservice teachers," in Proc. Society for Information Technology \& Teacher Education International Conference, pp. 2357-2366, 2017.

[40] M.-H. Lee and C.-C. Tsai, “Exploring teachers' perceived self-efficacy and technological pedagogical content knowledge with respect to educational use of the World Wide Web," Instructional Science, vol. 38, no. 1, pp. 1-21, 2010.

[41] H. M. Yaghi, "Subject matter as a factor in educational computing by teachers in international settings," Journal of Educational Computing Research, vol. 24, no. 2, pp. 139-154, 2001.

[42] A. Ottenbreit-Leftwich, K. D. Glazewski, T. J. Newby, and P. A. Ertmer, "Teacher value beliefs associated with using technology: Addressing professional and student needs," Computers \& Education, vol. 55, pp. 1321-1335, 2010.

[43] W. Thinzarkyaw, "The practice of technological pedagogical content knowledge of teacher educators in education colleges in Myanmar," Contemporary Educational Technology, vol. 11, no. 2, pp. 159-176, 2019.

[44] G. Bas and C. Senturk, "An evaluation of technological pedagogical content knowledge (TPACK) of in-service teachers: A study in Turkish public schools," International Journal of Educational Technology, vol. 5, no. 2, pp. 46-58, 2018.

[45] D. A. Schmidt, E. Baran, A. D. Thompson, P. Mishra, M. J. Koehler, and T. S. Shin, "Technological pedagogical content knowledge (TPACK): The development and validation of an assessment instrument for preservice teachers," Journal of Research on Technology in Education, vol. 42, no. 2, pp. 123-149, 2009.

[46] A. A. Khan, S. Niazi, and S. K. Saif. (March 2020). Universities unprepared for switch to remote learning. University World News. [Online]. Available: https://www.universityworldnews.com/post.php?story=20200326141 547229

[47] L. Voice. (June 2020). COVID-19 has exposed our schools as unprepared for a technology-filled present and future. BK Reader [Online].

Available: https://www.bkreader.com/2020/06/15/covid-19-has-exposed-our-sch ools-as-unprepared-for-a-technology-filled-present-and-future/

[48] T. Garcia. (March 2020). Most schools are completely unprepared for coronavirus and virtual learning. PBS News Hour. [Online]. Available: https://www.pbs.org/newshour/education/most-schools-are-completel y-unprepared-for-coronavirus-and-virtual-learning

[49] M. Casal. (August 2020). The pandemic is reshaping education, here's how the Philippines is coping. Rappler Philippines. [Online]. Available: https://rappler.com/brandrap/tech-and-innovation/coronavirus-reshapi ng-distance-learning-education-philippines

[50] J. Castillo. (August 2020). Globe, DepEd hold training to keep teachers, learners safe online. Manila Bulletin. [Online]. Available: https://mb.com.ph/2020/08/01/globe-deped-hold-training-to-keep-teac hers-learners-safe-online/

[51] R. A. Salac and Y. S. Kim, "A study on the internet connectivity in the Philippines," Asia Pacific Journal of Business Review, vol. 1, no. 1, pp 67-88, 2016.

[52] M. Tucay. (June 2015). K-12: Who loses, who profits. Inquirer.Net. [Online]. Available https://opinion.inquirer.net/85551/k-12-who-loses-who-profits

[53] E. Alampay, "Incorporating participation in the Philippines' e-LGU project," Region Development Dialogue, vol. 27, no. 2, p. 189, 2007.

[54] K. J. P. Espinosa and J. D. L. Caro, "Analysis of ICT integration initiatives in basic education and lessons learned: The case of the Philippines," presented at 2011 First ACIS/JNU International Conference on Computers, Networks, Systems and Industrial Engineering IEEE, 2011

[55] A. R. Lorenzo, "Effectiveness of the computer and internet literacy project in public high schools of Tarlac Province, Philippines," The Turkish Online Journal of Educational Technology, vol. 15, no. 2, pp. 38-46, 2016.

[56] F. Boschman, S. McKenney, and J. Voogt, "Exploring teachers' use of TPACK in design talk: The collaborative design of technology-rich early literacy activities," Computers \& Education, vol. 82, pp. 250-262, 2015.

[57] P. S. Hsu, "Examining current beliefs, practices and barriers about technology integration: A case study," TechTrends, vol. 60, no. 1, pp. 30-40, 2016.

[58] C. P. Lim, Y. Zhao, J. Tondeur, C. S. Chai, and T. Chin-Chung, "Bridging the gap: Technology trends and use of technology in schools," Journal of Educational Technology \& Society, vol. 16, no. 2 , pp. 59-68, 2013.

[59] Bussiness World. (January 2021). Schools in low-income countries are embracing 'low-tech' solutions amid the pandemic [Online]. Available: https://www.bworldonline.com/schools-in-low-income-countries-areembracing-low-tech-solutions-amid-the-pandemic/

[60] K. Gorgen and T. McAleavy. (June 2020). Report for EdTech Hub. An international review of plans for school reopening. Education Development Trust. [Online]. Available: https://edtechhub.org/wp-content/uploads/2020/09/School-Reopening -Report-EdTechHub-1.pdf

[61] International Labour Organization and World Bank. Skills development in the time of COVID-19: Taking stock of the initial responses in technical and vocational education and training. [Online] Available:

https://www.ilo.org/wcmsp5/groups/public/---ed_emp/---ifp_skills/do cuments/publication/wcms_766557.pdf

[62] L. Darling-Hammond, L. Flook, C. Cook-Harvey, B. Barron, and D. Osher, "Implications for educational practice of the science of learning 
and development," Applied Developmental Science, vol. 24, no. 2, pp. 97-140, 2020.

[63] G. McKnight-Tutein and A. S. Thackaberry, "Having it all: The hybrid solution for the best of both worlds in women's postsecondary education," Distance Learning, vol. 8, no. 3, pp. 17-22, 2011.

[64] N. Selwyn, "The use of computer technology in university teaching and learning: A critical perspective," Journal of Computer Assisted Learning, vol. 23, pp. 83-94, 2007.

[65] S. J. Yoo and W. D. Huang, "Engaging online adult learners in higher education: Motivational factors impacted by gender, age, and prior experiences," Journal of Continuing Higher Education, vol. 61, no. 3 , pp. 151-164, 2013.

[66] S. A. Brown, "Seeing web 2.0 in context: A study of academic perceptions," Internet and Higher Education, vol. 15, no. 1, pp. 50-57, 2012.

[67] R. C. Clark and R. E. Mayer, E-Learning and the Science of Instruction: Proven Guidelines for Consumers and Designers of Multimedia Learning, Hoboken, NJ: John Wiley \& Sons, 2016.

[68] A. Sadaf, T. Newby, and P. Ertmer, "An investigation of the factors that influence preservice teachers' intentions and integration of web 2.0 tools," Educational Technology Research \& Development, vol. 64, no. 1, pp. 37-64, 2016.

[69] I. Paus-Hasebrink, C. W. Wijnen, and T. Jadin, "Opportunities of web 2.0: Potentials of learning," International Journal of Media \& Cultural Politics, vol. 6, no. 1, pp. 45-62, 2010.

[70] Y. J. An and C. Reigeluth, "Creating technology enhanced, learner centered classrooms: K-12 teachers' beliefs, perceptions, barriers, and support needs," Journal of Digital Learning in Teacher Education, vol. 28 , no. 2, pp. 54-62, 2012.

[71] L. Warham, T. Gurney, M. Wingfield, C. Ring, G. Lowe, and G. Hughes, "Edtech: Keeping up with the pace of change," Education Technology, vol. 28, pp. 44-50, 2017.

[72] J. C. M. Tanucan, "Pedagogical praxis of millennial teachers in mainstreamed physical education," International Journal of Advanced Research. vol. 7, no. 1, pp. 554-562, 2019.

[73] J. C. M. Tanucan and M. R. A. Hernani, "Physical education curriculum in standard-based and competency-based education," International Journal of Health, Physical Education and Computer Science in Sports, vol. 30, no. 1, pp. 26-33, 2018.

[74] P. A. Ertmer, A. T. Ottenbreit-Leftwich, O. Sadik, E. Sendurur, and P. Sendurur, "Teacher beliefs and technology integration practices: A critical relationship," Computers and Education, vol. 59, no. 2, pp. 423-435, 2012

[75] E. Ifinedo, M. Saarela, and T. Hämälänen, "Analysing the Nigerian teacher's readiness for technology integration," International Journal of Education and Development Using Information and Communication Technology (IJEDICT), vol. 15, no. 3, pp. 34-52, 2019.

Copyright $\odot 2021$ by the authors. This is an open access article distributed under the Creative Commons Attribution License which permits unrestricted use, distribution, and reproduction in any medium, provided the original work is properly cited (CC BY 4.0).

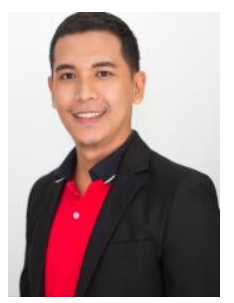

Jem Cloyd M. Tanucan is a full-time faculty member of the College of Teacher Education in Cebu Normal University (CNU) teaching professional education major courses and physical education major courses for undergraduate degree programs including research courses. Concurrently, he is a teaching internship mentor and sports and wellness coordinator of CNU-Integrated Laboratory School. Prior to his caree in $\mathrm{CNU}$, he served as the Music, Arts, Physical
Education, and Health Department Head for many years in Tayud National High School which provided him with a decent network collaboration in the Department of Education, wide experience in public educational leadership, and a strong grasp of the curriculum and instruction in the basic education. Trained in several local and international professional development seminars and workshops in research and leadership, Dr. Tanucan has led several institutionally-funded research projects that were published in various international reputable journals and registered several Utility Models in the Intellectual Property Office of the Philippines. Currently, he has been working with several utility models and research projects funded by $\mathrm{CNU}$ research office. He also garnered several awards in research including his recent national awards - Best Research Paper and Best in Oral Presentation during the 2nd National Gender and Development Research Congress organized by Central Luzon State University last November 2020.

He finished his Bachelor's degree specializing in Music, Arts, and Physical Education at the University of San Carlos as a CHED scholar on 2012 and graduated with his master's degree specializing in Physical Education at CNU on 2017. He is about to finish his doctorate degree - Doctor of Philosophy in Education major in Research and Evaluation at CNU as a faculty-scholar and a recipient of Commission on Higher Education Dissertation Grant on 2021. His research interests are physical education curriculum and instruction, sports sociology, wellness, education management and evaluation.

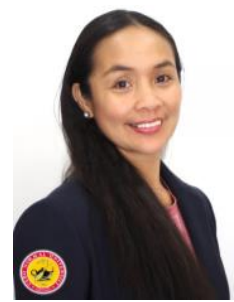

Ma. Rosita A. Hernani is the chair of the Chair Kinesthetic Department of Cebu Normal University. She is a prolific teacher and a multi-awarded researcher who received various local and international awards including the International Federation of Physical Education, Fitness and Sports Science Association Awards on 2019, Presidential Award given by International Organization for Health, Sports, and Kinesiology - IOHSK on 2020. He research interests are physical education curriculum and instruction, sports sociology, wellness, education management and evaluation.



Felix M. Diano Jr. was born in Maravilla, Tabuelan, Cebu, Philippines on April 29, 1993. He finished his Bachelor of Secondary Education (Magna Cum Laude) and Master of Arts in Education with specialization in Mathematics at the University of the Visayas in 2014 and 2016, respectively. Presently, he is a candidate for Doctor of Philosophy in Education major in Research Evaluation at Cebu Normal University.

He worked as an instructor at the University of the Visayas and later became a research coordinator in the College and Graduate School of Education for at least 6 years. Currently, he is the OIC-Dean of the College and Graduate School of Education and the Campus Administrator of the University of the Visayas Main Campus and Pardo Campus, respectively.

Prof. Diano is an active member of the Philippine Association for Teachers and Educators (PAFTE) and Coalition for Better Education (CBE) Moreover, he received various awards in Research, Mathematics, and Leadership. To name a few, he was awarded as "Best Research Presenter" during the 1st International Conference on Interdisciplinary Research held at the Colegio de San Juan de Letran, Manila, Philippines and received a "Certificate of Merit" given by the RAFI-Eduardo Aboitiz Development Studies Center. 